\title{
Aktivitas Antibakteri In-Vitro Ekstrak Etanol Beberapa Jenis Tanaman Krokot (Portulaca sp)
}

\author{
Agus Purwanto \\ Prodi Biologi, Universitas Katolik Widya Mandala Surabaya Kampus Kota Madiun, Jl. Manggis 15-17, Madiun, 63131 \\ E-mail: aguspurwanto@widyamandala.ac.id
}

\begin{abstract}
Purslane has antibacterial benefits. The diversity of purslane plants from the genus Portulaca is about 40-100 species found in tropical and four-season areas. The aim of this study was to test the in-vitro antibacterial potential of the ethanol extract of some purslane (Portulaca sp) cultivars against the tested bacteria. In-vitro antibacterial activity testing was performed using the disc diffusion method. This study used Portulaca oleracea and Portulaca grandiflora purslane cultivars. The results of the observation of the antibacterial activity testing of several cultivars of Portulaca grandiflora (K1, K3) and Portulaca oleracea (K2) against the test bacteria Staphylococcus aureus, Escherichia coli, and Pseudomonas aeruginosa were able to show antibacterial activity with various inhibition zones ranging between $1.56 \mathrm{~cm}$ and $2.86 \mathrm{~cm}$. Based on the results of testing for antibacterial activity of several cultivars of purslane plant, it was shown that the sensitivity of the Gram-positive test bacteria Staphylococcus aureus was higher than the Gram-negative test bacteria Escherichia coli and Pseudomonas aeruginosa.
\end{abstract}

Keywords — : Portulaca oleracea; Portulaca grandiflora; disc diffusion method.

\section{PENDAHULUAN}

Portulaca oleracea L. adalah tanaman herba tahunan yang bersifat kosmopolitan. Tanaman krokot umumnya dikenal sebagai kroklan (AS dan Australia), rigla (Mesir), pigweed (Inggris), pourpier (Prancis), dan Ma-Chi-Xian (Cina) (Elkhayat et al., 2008). Penyebaran tanaman krokot secara luas di daerah tropis dan subtropis, termasuk banyak bagian dari Amerika Serikat dan dikonsumsi secara luas sebagai bahan tambahan menu makanan dan salad di sekitar Mediterania dan negara-negara Asia tropis (Palaniswamy et al., 2002). Orang Amerika dan Aborigin Australia menggiling biji tanaman tersebut menjadi tepung untuk digunakan dalam bubur dan roti (Mohamed and Hussein, 1994). Portulaca oleracea juga menyediakan gizi yang bermanfaat karena kaya asam lemak omega-3 yang bersifat antioksidan (Palaniswamy et al., 2002).

Portulaca oleracea telah digunakan sebagai obat tradisional di banyak negara, bertindak sebagai obat penurun panas, antiseptik, obat cacing, dan sebagainya (Lee et al., 2012). Manfaat zat aktif tanaman krokot juga menunjukkan berbagai efek farmakologis, termasuk antibakteri (Zhang et al., 2002), antiulserogenik (Karimi, 2004), antiinflamasi (Chan et al, 2000), antioksidan (Chen et al., 2012), dan sifat penyembuhan luka (Rashed et al., 2003).

Tanaman krokot ditetapkan oleh Organisasi Kesehatan Dunia sebagai salah satu tanaman obat yang paling banyak digunakan, dan telah diberi istilah "Global Panacea" (Xu and Chen, 2006). Cerita kuno rakyat Cina menggambarkannya sebagai "sayuran untuk umur panjang" dan telah digunakan selama ribuan tahun dalam Pengobatan Cina tradisional (Chen et $a l ., 2009)$. Bersifat dingin di alam dan berasa asam yang digunakan untuk mendinginkan darah, menghentikan pendarahan, membersihkan panas, dan menetralisir racun. Bagian tanaman aerial yang dikeringkan menunjukkan khasiat untuk pengobatan demam, disentri, diare, karbunkel, eksim, dan hematochezia, dengan dosis yang dianjurkan 9-15 g (Zhao et al., 2014). Portulaca oleracea memiliki aktivitas antibakteri, antijamur, dan antivirus seperti yang diungkapkan oleh dermatofit efek antijamur dari genus Trichophyton (Oh et al., 2000).

Keragaman tanaman krokot dari genus Portulaca sekitar 40-100 spesies yang ditemukan di daerah tropis dan daerah bermusim empat. Belum semua species krokot telah diuji aktivitas antibakterinya. Berdasarkan hal tersebut maka perlu dilakukannya penelitian terkait dengan aktivitas antibakteri in-vitro ekstrak etanol beberapa jenis tanaman krokot (Portulaca sp).

Tujuan penelitian adalah untuk menguji potensi antibakteri in-vitro ekstrak etanol beberapa tanaman krokot (Portulaca sp) terhadap bakteri uji Escherichia coli, Pseudomonas aeruginosa, dan Staphylococcus aureus.

\section{METODE PENELITIAN}

\section{A. Bakteri Uji dan Kondisi Kultur}

Untuk keperluan uji in-vitro disiapkan satu isolat klinis Gram positif (Staphylococcus aureus) dan bakteri Gram-negatif (Escherichia coli dan Pseudomonas aeruginosa). Penyiapan inokulum bakteri uji dilakukan dengan membuat sub kultur murni pada agar miring NA pada suhu 
Website : http://agritek.unmermadiun.ac.id/index.php/agritek

kamar. Untuk uji aktivitas antibakteri, bakteri secara aerobik dikulturkan dalam NB pada suhu kamar selama 24 jam, dan kemudian disuspensikan dalam $\mathrm{NaCl}$ 0,9\% steril sampai densitasnya ekuivalen dengan standar McFarland 0.5 pada panjang gelombang $600 \mathrm{~nm}$ yang setara dengan konsentrasi $10^{5} \mathrm{cfu} / \mathrm{ml}$ selanjutnya digunakan untuk uji in vitro aktivitas antibakteri.

\section{B. Ekstraksi Tanaman Krokot}

Penyiapan ekstraksi dilakukan dengan mengambil bagian aerial tanaman krokot sebanyak $3 \mathrm{~kg}$ dibersihkan dengan air mengalir, selanjutnya dicuci dengan akuades dan dikeringanginkan selama 5 (lima) hari pada suhu $50^{\circ} \mathrm{C}$ dengan oven sampai mendapatkan simplisia kering. Selanjutnya simplisia kering dihaluskan dengan blender sehingga diperoleh serbuk simplisia dan ditimbang. Kemudian serbuk simplisia krokot dilakukan maserasi dengan cara merendam serbuk simplisia kering dengan etanol 70\% dengan perbandingan 1 gram serbuk simplisia dan 7 (tujuh) $\mathrm{ml}$ etanol. Maserasi dilakukan selama 7 hari dan dilakukan pengadukan setiap harinya. Hasil maserasi (maserat) selanjutnya disaring dengan kertas saring kemudian dievaporasi dengan rotary evaporator sampai mendapatkan ekstrak kental. Selanjutnya ekstrak kental dituang ke cawan petri dan dioven pada suhu $50^{\circ} \mathrm{C}$ untuk menghilangkan sisa etanol dan selanjutnya disimpan di lemari es sampai dengan penggunaan selanjutnya (Lolo et al., 2017).

\section{Pembuatan Larutan krokot dalam DMSO}

Penimbangan ekstrak kental krokot sebanyak 1 gram, kemudian dilarutkan dalam10 ml DMSO 10\% untuk mendapatkan larutan ekstrak krokot $10 \%$ dengan konsentrasi 0.1 gram per ml. Selanjutnya disimpan dalam tabung eppendorf 5 ml dan disimpan di lemari pendingin sampai dengan pegujian selanjutnya.

\section{Pengujian Aktivitas Antibakteri Metode Difusi Cakram}

Metode difusi sumuran digunakan untuk uji antimikroba (Baur et al., 1966). Penuangan $1 \mathrm{ml}$ 1,5x108 bakteri/ml dengan mikropipet masing-masing strain bakteri larutan bakteri ke lempeng agar nutrien yang disiapkan sebelumnya. Suspensi bakteri tersebut kemudian diinokulasikan secara merata menggunakan spreader secara aseptis di seluruh permukaan cawan petri. Kemudian menyiapkan $100 \%$ konsentrasi ekstrak tanaman krokot yang sudah disiapkan dalam tabung eppendorf untuk merendam paper disk selama 30 menit. Langkah berikutnya untuk uji aktivitas antibakteri dilakukan menggunakan cawan petri yang telah diinokulasi dengan suspensi bakteri. Setiap Cawan petri dibagi menjadi 4 kuadran yaitu berisi paper disk yang telah direndam dengan ekstrak tanaman krokot (kuadran 1-3), kuadran 4 untuk kontrol positif yang menggunakan larutan infus antibiotik siprofloksasin sebanyak $100 \mu$ l. Sedangkan dibagian tengah cawan petri untuk kontrol negatif menggunakan larutan $\mathrm{NaCl} 0,9 \%$.

Kondisi inkubasi semua lempeng agar dilakukan pada suhu kamar selama 24 jam. Langkah terakhir adalah mengamati zona hambat yang terbentuk di sekitar paper disk dengan mengukur besarnya diameter zona hambatan yang diukur dalam milimeter dengan jangka sorong.

\section{E. Analisis Data}

Untuk mengetahui aktivitas antibakteri in-vitro ekstrak etanol beberapa jenis tanaman krokot (Portulaca sp), data hasil pengukuran ratarata diameter zona hambat yang dihasilkan dianalisis dengan menggunakan analisis varians pada tingkat signifikansi $5 \%(\alpha=0,05)$. Jika terdapat beda nyata dilanjutkan dengan uji BNT pada $\alpha=0,05$.

\section{III.HASIL DAN PEMBAHASAN}

\section{A. Deskripsi Botani Tanaman Krokot}

\section{Portulaca grandiflora Kultivar K1}

Portulaca grandiflora kultivar K1 batang bulat dan padat, batang tegak dan merebah, berambut tipis halus pada batas ruas batangnya, warna batang coklat muda, diameter 2.7-5 mm. Daunnya tunggal, tidak bertangkai (sesilis), warna hijau mengkilat, berdaging tebal, berair, dan agak lunak, bentuk daun linier atau silindris (menyerupai daun cemara), susunan daun menyebar, berselang-seling, panjang daun 30-35 mm, panjang daun 1-3 cm, tepi rata dengan ujung runcing dan pangkal tumpul. Bunga biseksual, majemuk, letaknya di ujung cabang, warna merah jambu, bentuk seperti mawar, ukuran bunga 25-35 $\mathrm{mm}$.

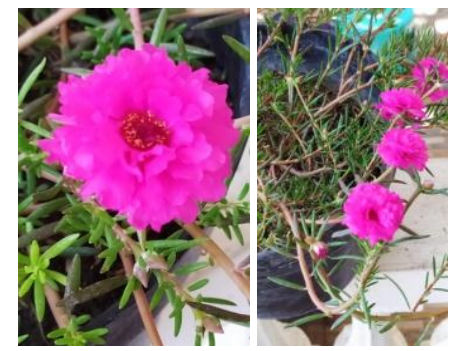

Gambar 1. Morfologi Portulaca grandiflora kultivar K1

\section{Portulaca oleracea Kultivar K2}

Portulaca oleracea kultivar K2 sukulen, batang herba aerial, bulat, berdaging, gundul (glabrous), licin, warna kemerahan, silindris, tumbuh tegak hingga 20-25 cm, diameter 2-3 mm. Daunnya tunggal, sessilis (bertangkai pendek), sukulen (berdaging dan berair), 
warna permukaan hijau mengkilap dan bagian bawah permukaan daun hijau, panjang 1-3 cm dan lebar 1-2 $\mathrm{cm}$, bentuk daun bulat telur sungsang (obovatus), bagian ujungnya membulat dan pangkalnya tumpul, tepi daun rata, letak daun berhadapan atau tersebar. Bunga sesil, muncul tunggal diujung batang, biseksual, mahkota bunga 5 buah, warna kuning cerah dan ukuran kecil 3-5 mm.

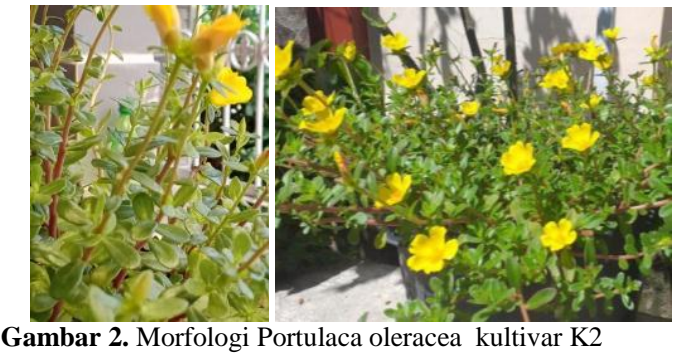

\section{Portulaca grandiflora Kultivar K3}

Portulaca grandiflora kultivar K3 batang bulat dan padat, batang tegak dan merebah, berambut tipis halus pada batas ruas batangnya, warna batang hijau muda, diameter 2-3 mm. Daunnya tunggal, tidak bertangkai (sesilis), warna hijau mengkilat, berdaging tebal, berair, dan agak lunak, bentuk daun linier atau silindris (menyerupai daun cemara), ujung runcing dan pangkal tumpul panjang daun 25-30 cm, susunan daun menyebar, berselang-seling. Bunga biseksual, majemuk, letaknya di ujung cabang, warna pink sembur putih di pinggir, bentuk seperti mawar, ukuran bunga $25-30 \mathrm{~mm}$.

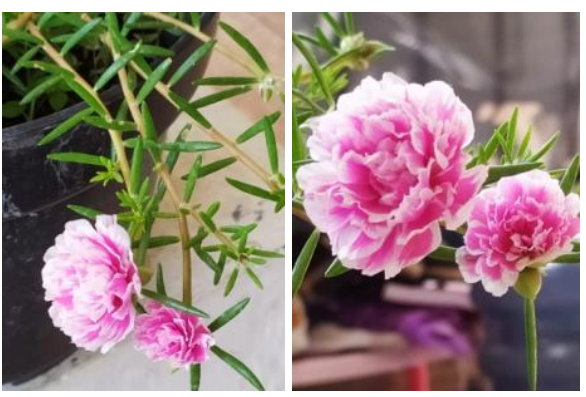

Gambar 3. Morfologi Portulaca grandiflora kultivar K3

Hasil pengamatan yang dilakukan melalui pengamatan karakteristik morfologi krokot Portulaca grandiflora pada kultivar K1 dan K3 secara umum mempunyai ciri-ciri bentuk batang bulat dan padat, batang tegak dan merebah, berambut tipis halus pada batas ruas batangnya. Daun tunggal, tidak bertangkai (sesilis), warna hijau mengkilat, berdaging tebal, berair, dan agak lunak, bentuk daun linier atau silindris (menyerupai daun cemara), susunan daun menyebar, berselang-seling, ujung runcing, pangkal tumpul, tepi rata, panjang daun 1-3 cm. Bunga biseksual, majemuk, letaknya di ujung cabang dengan seperti mawar. Hasil pengamatan morfologi ini sama dengan hasil observasi yang dilaporkan oleh beberapa peneliti sebelumnya (Setiawan et al., 2016). Perbedaan morfologi beberapa kultivar Portulaca grandiflora terdapat pada warna batang dan warna dan ukuran diameter bunga.

Sedangkan hasil pengamatan morfologi pada krokot Portulaca oleracea kultivar K2, secara umum mempunyai ciri-ciri sukulen, batang herba aerial dan tumbuh tegak, bentuk batang bulat, berdaging, gundul (glabrous), licin, warna coklat kemerahan, silindris, percabangan batang muncul pada pangkal batang yang bersinggungan dengan tanah. Daunnya tunggal, sessilis (bertangkai pendek), sukulen (berdaging dan berair), bentuk daun bulat telur sungsang (obovatus), bagian ujungnya membulat dan pangkalnya tumpul, tepi daun rata, letak daun berselang-seling atau tersebar. Bunga biseksual, sesil, muncul tunggal diujung batang, warna bunga kuning cerah Hasil observasi yang sama juga dilaporkan oleh Bagepalli et al, (2008) dan Uddin et al, 2014). Perbedaan karakteristik morfologi keanekaragaman kultivar (Portulaca oleracea) dibandingkan dengan krokot liar terdapat pada pertumbuhan rebah (krokot liar) dan tegak (erektil), perbedaan warna batang dan mahkota bunga.

\section{B. Hasil Pengujian Aktivitas Antibakteri Ekstrak Etanol Beberapa Kultivar Tanaman Krokot}

Hasil pengamatan hasil pengujian aktivitas antibakteri ekstrak etanol beberapa kultivar tanaman krokot (Tabel 1 dan Gambar 4) menunjukkan bahwa Portulaca grandiflora (K1, K3) dan Portulaca oleracea (K2) terhadap bakteri uji (Staphylococcus aureus, Escherichia coli, dan Pseudomonas aeruginosa) mampu menunjukkan aktivitas antibakteri dengan zona penghambatan yang beragam berkisar antara 1.56 $\mathrm{cm}$ dan $2.86 \mathrm{~cm}$.

Tabel 1. Hasil Uji Aktivitas Antibakteri In Vitro Ekstrak Etanol Beberapa Kultivar Tanaman Krokot terhadap Bakteri Uji

\begin{tabular}{|c|c|c|c|c|c|c|}
\hline \multirow{2}{*}{ Bakteri Uji } & \multicolumn{5}{|c|}{ Rerata Diameter Zona Hambat (cm) } \\
\cline { 2 - 7 } & $\mathrm{K} 1$ & $\mathrm{~K}+$ & $\mathrm{K} 2$ & $\mathrm{~K}+$ & $\mathrm{K} 3$ & $\mathrm{~K}+$ \\
\hline Staphylococcus aureus & $2.86^{\mathrm{b}}$ & $5.00^{\mathrm{c}}$ & $2.30^{\mathrm{a}}$ & $4.5^{\mathrm{b}}$ & $2.20^{\mathrm{b}}$ & $4.50^{\mathrm{c}}$ \\
\hline Escherichia coli & $2.00^{\mathrm{a}}$ & $5.00^{\mathrm{c}}$ & $2.20^{\mathrm{a}}$ & $4.6^{\mathrm{b}}$ & $1.76^{\mathrm{a}}$ & $4.30^{\mathrm{c}}$ \\
\hline $\begin{array}{c}\text { Pseudomonas } \\
\text { aeruginosa }\end{array}$ & $1.76^{\mathrm{a}}$ & $4.50^{\mathrm{c}}$ & $1.56^{\mathrm{b}}$ & $4.0^{\mathrm{b}}$ & $2.03^{\mathrm{b}}$ & $4.00^{\mathrm{c}}$ \\
\hline
\end{tabular}


Website : http://agritek.unmermadiun.ac.id/index.php/agritek

\section{Keterangan:}

*)Notasi (a,b,c) merupakan hasil uji Duncan dengan taraf kepercayaan 5\%, notasi yang sama menunjukkan tidak ada beda nyata dan notasi yang tidak sama menunjukkan perbedaan nyata.

**) K1, K3 adalah adalah Portulaca grandiflora kultivar K1 dan K3, sedangkan K2 adalah Portulaca oleracea kultivar K2, serta K+ merupakan kontrol positif.

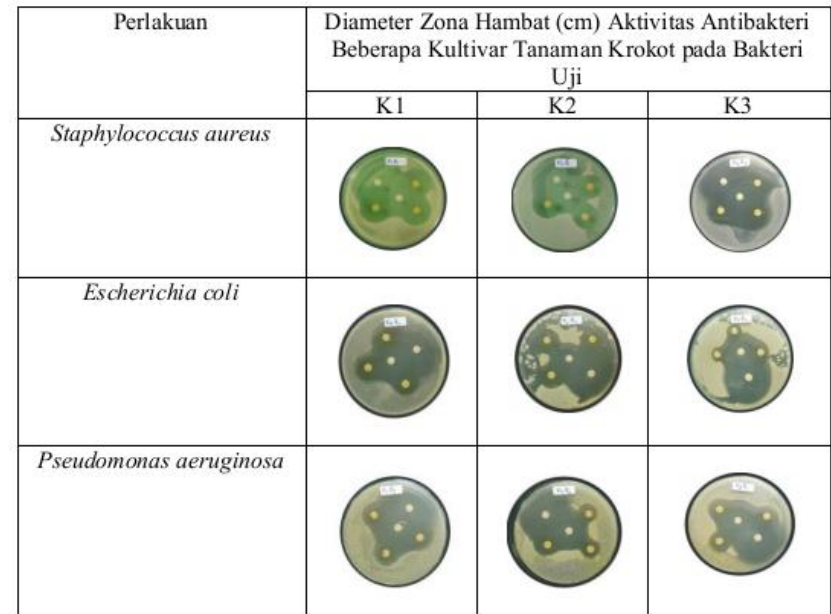

Gambar 4. Diameter Zona Hambat yang Terbentuk Hasil Pengujian Aktivitas Antibakteri Ekstrak Etanol Beberapa Kultivar Tanaman Krokot

Hasil pengujian daya hambat ekstrak etanol kultivar tanaman krokot K1 dengan K+ pada bakteri uji menghasilkan diameter zona hambat maksimum pada tanaman krokot kultivar K1 sebesar $2.86 \mathrm{~cm}$ diperoleh pada bakteri Staphylococcus aureus, sedangkan zona hambat minimum diperoleh pada bakteri Escherichia coli sebesar $2.00 \mathrm{~cm}$ dan Pseudomonas aeruginosa $1.76 \mathrm{~cm}$.

Hasil pengujian daya hambat ekstrak etanol kultivar tanaman krokot K2 dengan $\mathrm{K}+$ pada bakteri uji menunjukkan zona hambatan tertinggi sebesar $2.30 \mathrm{~cm}$ pada media tumbuh bakteri Staphylococcus aureus. Sedangkan diameter zona hambat pada Escherichia coli dan Pseudomonas aeruginosa masing sebesar sebesar $2.20 \mathrm{~cm}$ dan $1.56 \mathrm{~cm}$. Hasil daya hambat tanaman krokot K3 dengan K+ menghasilkan diameter zona hambat terbesar pada Staphylococcus aureus sebesar $2.20 \mathrm{~cm}$. Selanjutnya zona hambat minimum masing diperoleh bakteri Pseudomonas aeruginosa dan Escherichia coli masing-masing sebesar 2.03 dan $1.76 \mathrm{~cm}$.

Secara keseluruhan hasil uji aktivitas in vitro ekstrak etanol beberapa kultivar krokot species Portulaca oleracea dan Portulaca grandiflora (Tabel 1 dan Gambar 4) dapat dilaporkan bahwa rerata diameter zona hambat yang terbentuk pada bakteri uji Gram-positif Staphylococcus aureus lebih besar dibandingkan dengan bakteri uji Gram-negatif Escherichia coli dan Pseudomonas aeruginosa.

Menurut Nayaka et al., (2014) aktivitas antibakteri bakteri uji Gram-positif dan Gram-negatif, yaitu Pseudomonas aeruginosa, Salmonella typhimurium, Proteus mirabilis, Klebsiala pneumoniae, dan Enterobacter aaerogenes disebabkan adanya senyawa bioaktif flavonoid apigenin tanaman krokot yang berpotensi menghambat pertumbuhan bakteri patogenik yang diperlakukan. Selanjutnya dinformasikan juga bahwa senyawa aktif apigenin mempunyai aktivitas antibakteri yang lebih signifikan pada bakteri Gram-positif yang diperlakukan dibandingkan bakteri Gram-negatif yang diperlakukan. Adanya perbedaan tersebut kemungkinan disebabkan penghalang permeabilitas adanya struktur berlapis di luar dinding sel bakteri Gram-negatif atau adanya enzim dalam ruang periplasmik yang mampu memecah molekul asing dari luar sel bakteri.

Penelitian yang sama juga dilaporkan oleh Karlina et al., (2013) yang menyatakan bahwa ekstrak herba krokot lebih berpengaruh pada bakteri Gram positif Staphylococcus aureus dibandingkan dengan bakteri Gram-negatif Escherichia coli. Menurut Volk dan Wheeler (1988) adanya kandungan asam teikoat pada bakteri Gram-positif yang bersifat polar memudahkan senyawa aktif flavonoid yang terkandung pada tanaman krokot masuk ke dalam sel bakteri dibandingkan adanya senyawa lipopolisakarida yang bersifat non-polar pada pada bakteri Gramnegatif.

\section{IV.KESIMPULAN}

Hasil pengamatan hasil pengujian aktivitas antibakteri in-vitro ekstrak etanol beberapa kultivar tanaman Portulaca grandiflora (K1, K3) dan Portulaca oleracea (K2) terhadap bakteri uji (Staphylococcus aureus, Escherichia coli, dan Pseudomonas aeruginosa) mampu menunjukkan aktivitas antibakteri dengan zona penghambatan yang beragam berkisar antara $1.56 \mathrm{~cm}$ dan $2.86 \mathrm{~cm}$. Berdasarkan hasil pengujian aktivitas antibakteri beberapa kultivar tanaman krokot menunjukkan bahwa kepekaan bakteri uji Gram-positif Staphylococcus aureus lebih tinggi dibandingkan dengan bakteri uji Gram-negatif Escherichia coli dan Pseudomonas aeruginosa

\section{UCAPAN TERIMAKASIH}

Mengucapkan terima kasih kepada Universitas Katolik Widya Mandala Surabaya Kampus Kota Madiun melalui LP3M yang telah memberikan dana internal untuk penelitian dosen. Selanjutnya kepada Ketua Program Studi Farmasi D3 yang memberikan ijin dan fasilitasnya di laboratorium terpadu untuk melaksanakan penelitian. 
Website : http://agritek.unmermadiun.ac.id/index.php/agritek

\section{VI.DAFTAR PUSTAKA}

Bagepalli, SAK, Prabhakarn, V, Laksman, K, Nandeesh, R, Subhramanyam, P, Khan, S, Ranganayakalu, D, and Khrisna, NV. 2008. Pharmacognistical Studies of portulaca oleracea Linn. Brazillian Journal of Pharmacognosy, Vol 18(4):527-531.

Baur, AW, Kirby, WM, Sherris, JC, and Turck, 1966. Antibiotic Susceptibility Testing by a Standard Singgle Disc Method. Am J Clin Path; 45 : $493-496$.

Chan, K., Islam, M., and Kamil. 2000. The Analgesic and Anti-Inflammatory Effect of Portulaca oleracea L. Subssp. Sativa (Haw.) Celak. Journal of Ethnopharmacology, Vol. 73.

Chen, C,J., W.Y. Wang, and X.L. Wang. 2009. Anti-Hypxic Activity of the Ethanol Extract from Portulaca oleracea in Mice. Journal of Ethxdnopharmacology, vol. 224, no. 2.

Elkhayat, E.S, S.R,M Ibrahin., and M.A, Aziz,. 2008. Portulene, A New Diterpene from Portulaca oleracea L, Journal of Asian Natural Product Reseach, vol.4, No. 11-12.

Karimi, G., H. Hosseinzadeh, and H. Ettehad. 2004. Evaluation of The Gastric Antiulcerogenic effect of Portulaca oleracea L Extract in Mice. Phytotherapy Research, vol. 18

Karlina, SY, Ibrahin, M, dan Trimultyono (2013). Aktivitas Antibakteri Ekstrak Herba Krokot (Portulaca oleracea L) terhadap Staphylococcus aureus dan Escherichia coli. Jurnal LenteraBio, Vol.2 No. 1.

Lee, A.S., J.S. Kim,S., D.G., Kang, and H.S. Lee. 2012. Anti-TNF- $\alpha$ Activity of Portulaca oleracea in Vascular Endothelial Cells, International Journal of Molecular Science, vo. 13 no. 5 .

Lolo, WA, Sudewi, S, dan Edy, HJ. 2017. Penentuan Nilai Sun Protecting Factor (SPF) Herba Krokot (Portulaca oleracea L.). JPSCR. 2(1):1-5.

Mohamed, A.I. and A.S. Hussein. 1994. Chemical Composition of Purslane (Portulaca oleracea), Plant Foods for Human Nutrition, vol 45. No.1.

Nayaka, HB, Londonkar, RL, Umesh, MK, dan Tukappa, A. 2014. Antibacterial Attribute of Apigenin, Isolated from Portulaca oleracea L. Hindawi Publishing Corporation. International Journal of Bacteriology.

Oh, K.B., M. Chang, K.J. Hwang and W. Mar. 2000. Detection of Antifungal Activity in Portulaca oleracea by Single-Cell Bioassay System, Phytotherapy Research, vol. 14, no. 5 .

Palaniswamy, U.R., B.B. Bible,., and R.J McAvoy,. 2002. Effect of Nitrate: Ammonium Nitrogen ratio on Oxalate Levels of Purslane, Trend in New Crops and New Uses, vol. II, no. 5.

Rashed, A.N., F.U. Afifi, and A.M. Disi. 2003. Simple Evaluation of The Wound Healing Activity of a Crude Extract of Portulaca oleracea L (Growing in Jordan) in Mus musculus JVI-1. Journal of Ethnopharmacology, vol. 88

Setiawan, FID, Aisyah, SI, dan Krisantini, K. 2016. Characterization of 13 Accession of Purslane (Portulaca sp) from Bogor, West Java, Indonesia. Journal of Tropical Crop Science, Vol 3, No.3.

Uddin, M.K., A.S. Juraimi, M.S. Hossain, M.A.U. Nahar, M.E. Ali, and M.M. Rahman. 2014. Purslane weed (Portulaca oleracea): A prospective Plant Source of Nutrition, Omega-3 Fatty Acid, and antioxidant Attributes, The Scientific World Journal.

Volk dan Wheeler. 1988. Mikrobiologi Dasar Edisi ke-5. Penerbit Erlangga, Jakarta.

Xu, X., L. Yu and G. Chen. 2006. Determination of Flavonoids in Portulaca oleracea L by capillary Electrophoresis witj Electrochemical Detection. Journal of Pharrmaceutical and Biomedical Analysis. Vo. 42, no. 2

Zhao, C.Q., Y. Zhou, J. Ping, and M. Xu. 2014. Traditional chinese Medicine for Treatment of Liver Diseases: Progress, Challengs and Opportunities. Journal of integrative Medicine, Vol. 12, no. 5.

Zhang, X.J., Y.B. Ji, Z.Y., Qu, and L. Wang, L. 2002. Experimental Studies on Antibiotic Functions of Portulaca oleracea L In Vitro. Chinese Journal of Microecology, vol. 14 